\title{
VARIASI BAHASA DALAM DIALOG TOKOH FILM TOBA DREAMS GARAPAN BENNY SETIAWAN
}

\author{
Leo Wira Hardiono \\ Universitas Negeri Surabaya \\ Jl. Ketintang,Kec Gayungan, Kota Surabaya, Indonesia \\ Pos-el: leowirahardiono17@gmail.com
}

\begin{abstract}
Language variety is a variant of a language according to usage. This study was conducted to determine the use of language variations in terms of speakers in the movie Toba Dreams director Benny Setiawan. In the film there are some characters who have different ethnic backgrounds and sociology. This study aims to describe dialect and sociology in the dialogue between characters in the movie Toba Dreams. The method used in this research is qualitative descriptive. Provision of data is done by the method refer, by listening and understand the language data in the form of spoken language in the data source dialogue between characters. Technique used is technique record and record. Results from the study. 1) the form of dialect variation, 2) sociolek in dialogue between characters. The results of this study can be used as a reading material for the understanding of the community when viewing the movie Toba Dreams.
\end{abstract}

Keywords: language variation, sociolek, dialogue figure, toba dreams

\begin{abstract}
Abstrak
Ragam bahasa merupakan varian dari sebuah bahasa menurut pemakaian. Penelitian ini dilakukan untuk mengetahui pemakaian variasi bahasa dari segi penutur dalam film Toba Dreams garapan Benny Setiawan. Dalam film tersebut terdapat beberapa tokoh yang memunyai latar belakang etnis berbeda beserta sosioleknya. Penelitian ini bertujuan mendeskripsikan dialek dan sosiolek dalam dialog antar tokoh di film Toba Dreams. Metode yang digunakan dalam penelitian ini adalah deskriftif kualitatif. Penyediaan data dilakukan dengan metode simak, dengan menyimak dan memahami data-data kebahasaan yang berupa bahasa lisan dalam sumber data dialog antar tokoh. Teknik yang digunakan adalah teknik rekam dan catat. Hasil dari penelitian. 1) wujud variasi dialek, 2) sosiolek dalam dialog
\end{abstract}


antartokoh. Hasil dari penelitian ini dapat digunakan sebagai bahan bacaan untuk pemahaman masyarakat ketika melihat film Toba Dreams.

Kata-kata Kunci: Variasi bahasa, sosiolek, dialog tokoh, toba dreams.

\section{PENDAHULUAN}

Sebuah tayangan dalam media yang dikonsumsi masyarakat dalam televisi atau bioskop mengandung sebuah fenomena. Cuplikan yang ditayangkan tersebut mengandung sebuah bahasa yang baru dan akan berkembang dalam masyarakat. Penyangangan dalam media televisi atau bioskop perlu adanya kajian yang nantinya kita tidak hanya mengetahui jalan ceritanya saja tapi juga mengetahui penggunaan bahasa setiap tokohnya.

Film merupakan media komunikasi massa untuk mengkomunikasikan tentang suatu realita yang terjadi dalam kehidupan sehari-hari, film memiliki realitas yang kuat salah satunya menceritakan tentang realitas masyarakat. Menurut Effendi (2007:239) film diartikan sebagai hasil budaya dan alat ekspresi kesenian. Film sebagai komunikasi massa merupakan gabungan dari berbagai teknologi seperti fotografi dan rekaman suara, kesenian baik seni rupa dan seni teater sastra dan arsitektur serta seni musik.

Toba dreams karya yang sebelumnya merupakan gubahan dari novel karya mantan Menteri Negara Pendayagunaan Aparatur Negara di Kabinet Pembangunan VI semasa Presiden Soeharto, T.B. Silalahi. Dalam film tersebut ada beberapa variasi bahasa dialek antar tokoh karena perbedaan etnis seperti tokoh yang dilahirkan dengan keturunan ibunya dari Jawa dan ayahnya dari Batak. Tokoh Ibu Ronggur yang memang asli orang Jawa terkadang berbicara Jawa terhadap istri Ronggur. Film yang terbungkus dengan romantisme sarat makna ini mengisyaratkan bahwa perbedaan tidak akan mengalahkan sebuah rasa cinta pada keluarga. Sersan TB dengan watak keras yang mendidik anaknya memberikan gambaran mendidik dengan memkasakan prinsip hidup seorang tentara kepada keluarganya. Literasi memiliki definisi (lama) yakni kemampuan membaca dan menulis (7th Edition Oxford Advanced Learner's Dictionary, 2005: 898 dalam Alwasilah, 2012:159). Perkembangan literasi sangat cepat dengan disandingkannya kata literasi dengan disiplin ilmu yang lain: literasi matematika, literasi komunikasi, literasi komputer dan masih banyak lagi. Dengan literasi yang semakin Leo Wira Hardiono, Variasi Bahasa............. (1-13) 
berkembang dituntutlah pemahaman terhadap ilmu literasi yang lain semakin kompleks. Karancuan mungkin bisa terjadi karena perbedaan pemahaman antara literasi yang dulu dengan literasi definisi yang berkembang saat ini. Meskipun literasi disandingkan dengan bidang ilmu yang lain tetapi literasi tetap pada penggunaan bahasa dan kajiannya lintas disiplin yang memiliki tujuh dimensi yang saling mengait: dimensi geografis, bidang, keterampilan, fungsi, media, jumlah, dan bahasa. Dimensi jumlah merujuk pada banyak hal, misalnya bahasa, variasi bahasa, peristiwa tutur, bidang ilmu, media, dan sebagainya. Multitalerat mampu berinteraksi dalam berbagai situasi. Kemampuan tersebut tumbuh karena proses pendidikan yang berkualitas tinggi. Literasi, seperti halnya komunikasi, bersifat relatif (Alwasilah, 2012: 161-163).

Artikel ini bertujuan untuk mendeskripsikan dialek dan sosiolek yang difokuskan pada dialog antartokoh film Toba Dreams. Dalam artikel ini menggunakan pendekatan sosiolinguistik karena variasi atau ragam bahasa satu di antara bahasan pokok yang dianalisis. Menurut Kridalaksana (2008) sosiolinguistik adalah ilmu yang memperlajari ciri dan fungsi pelbagai variasi bahasa, serta hubungan di antara bahasa dengan ciri dan fungsi dalam suatu masyarakat bahasa. Menurut Chaer,
(2010:2) sosiolinguistik adalah bidang ilmu antardisiplin yang mempelajari bahasa dalam kaitannya dengan penggunaan bahasa itu di dalam masyarakat. Ilmu yang dipelajari antara lain struktur sosial dan proses-proses sosial, termasuk di dalamnya perubahan-perubahan sosial (Alwasilah, 2012:1). Struktur dan proses sosial yang dipelajari tidak lepas dari adanya dua aspek tingkah laku manusia yakni penggunaan bahasa dan organisasi tingkah laku manusia dalam Ohoiwutun, 2007:9). Penggunaan bahasa di tengah masyarakat yang saling bersosialisasi menghasilkan situasi-situasi bahasa yang bervariasi. Satu bahasa dengan bahasa yang lain akan sangat mempengaruhi, sebagaimana pernyataan Ohoiwutun (2007:9) bahwa sosiolinguistik berupaya menjelaskan kemampuan manusia menggunakan aturan-aturan berbahasa secara tepat dalam situasisituasi yang bervariasi. Rahadi (2010) merumuskannya dengan kajian yang berhubungan dengan penutur bahasa sebagai anggota masyarakat. Situasi yang terbentuk merupakan dorongan-dorongan sosial yang memicu penggunaan variasi bentuk bahasa di tengah lingkungan yang beraneka ragam. Alwasilah (2012:37) menyatakan bahwa sekelompok orang biasanya pada tempat yang sama, berbicara ragam bahasa yang sama, atau bahasa baku yang sama. 
Sekelompok orang ini kemudian akan menun-jukkan kesepakatan dan kaidah penggunaan bahasa yang berkaitan dengan aspek budaya dalam masyarakatnya (Wijana, 2010:11). Berdasarkan pernyataan ini dapat ditarik pernyataan bahwa setiap individu adalah anggota masyarakat ujaran dalam batasan satu dialek. Jika seseorang memiliki verbal repertoire yang luas maka dia akan mampu berkomu-nikasi dengan beberapa dialek atau ragam bahasa lain. Variasi bahasa ini berdasarkan kriteria (a) latar belakang geografi dan sosial penutur, (b) medium yang digunakan, dan (c) pokok pembicaraan (dalam Chaer dan Agustina, 2010:81).

Variasi atau ragam bahasa ada dua pandangan. Pertama, variasi atau ragam bahasa dilihat sebagai akibat adanya keragaman sosial penutur bahasa dan keragaman fungsi bahasa. Kedua, variasi atau ragam bahasa sudah ada untuk memenuhi fungsinya sebagai alat interaksi dalam kegiatan masyarakat yang beraneka ragam (Chaer dan Agustina, 2010:62). Tidak ada suatu bahasa di dunia ini yang tidak memiliki variasi. Variasi dapat berwujud perbedaan antara kelompok orang dan fungsi kegiatan dalam masyarakat sosial. Namun, variasi ini masih melingkupi pola atau dasar yang sama. Variasi ini antara lain disebabkan oleh pengaruh bahasa tetangga, seperti bentuk kosa kata, struktur, dan lafalnya (Keraf, 2008: 143). Menurut Chaer dan Agustina (2010: 62) variasi bahasa dibedakan berdasarkan penutur dan penggunaannya. Berdasarkan penutur, berarti siapa yang menggunakan bahasa itu, di mana tinggalnya, bagaimana kedudukan sosialnya di dalam masyarakat, apa jenis kelaminnya, dan kapan bahasa itu digunakannya. Berdasarkan penggunaannya, berarti bahasa itu digunakan untuk apa, dalam bidang apa, apa jalur dan alatnya, dan bagaimana situasi keformalannya. Chaer dan Agustina (2010:81) mengatakan bahwa variasi atau ragam bahasa dilihat sebagai akibat adanya keragaman sosial penutur bahasa dan keragaman fungsi bahasa. Variasi bahasa terbagi menjadi berbagai jenis, antara lain variasi dari segi penutur, pemakaian, keformalan, dan sarana. Teori tersebut sangat membatu untuk mengetahui variasi bahasa yang terdapat pada film Toba Dreams, khususnya yang mengandung variasi bahasa dialek dan sosiolek. Variasi dari segi penutur meliputi idiolek, dialek, sosiolek, dan kronolek. Idiolek adalah ujaran individu yang unik dimiliki oleh perseorangan (Alwasilah, 2012:42). Dialek merupakan suatu ragam bahasa yang dikaitkan dengan sekelompok penutur tertentu dan Leo Wira Hardiono, Variasi Bahasa.............. (1-13) 
saling mengerti dengan ragamragam lainnya (Alwasilah, 2012:43). Sosiolek adalah variasi bahasa yang berkenaan dengan status, golongan, dan kelas sosial para penuturnya. Kronolek atau dialek temporal yaitu variasi bahasa yang digunakan oleh kelompok sosial pada masa tertentu. Dalam artikel ini pembahasan yang diambil terkait dengan variasi bahasa dialek dan sosiolek dengan mengamati dialog antar tokoh film Toba Dreams.

Istilah sosiolinguistik ini muncul pada tahun 1952 dalam karya Haver C. Currie yang merupakan gabungan kata sosiologi dan linguistik. Sosiologi itu adalah kajian yang objektif dan ilmiah mengenai manusia di dalam masyarakat, mengenai lembaga-lembaga, dan proses sosial yanga ada di dalam masyarakat. Sedangkan linguistik adalah bidang ilmu yang mempelajari bahasa, atau bidang ilmu yang mengambil bahasa sebagai objek kajianya.

Dengan demikian, dapat dikatakan bahwa sosiolinguistik adalah bidang ilmu yang mempelajari bahasa dalam kaitannya dengan penggunaan bahasa itu sendiri dalam masyarakat.

Menurut Kridalaksana (2008), sosiolinguistik lazim didefinisikan sebagai ilmu yang mempelajari ciri dan pelbagai variasi bahasa serta hubungan di antara para bahasawan dengan ciri fungsi variasi bahasa itu di dalam suatu masyarakat bahasa. Selanjutnya, Rahadi (2010:3), pengkajian bahasa dengan dimensi kemasyarakatan juga disebut dengan sosiolinguistik.

Jadi, sosiolinguistik lebih berhubungan dengan perincian-perincian penggunaan bahasa yang sebenarnya, seperti deskripsi polapola pemakaian bahasa/dialek dalam budaya tertentu, pilihan pemakaian bahasa/dialek tertentu yang dilakukan penutur, topik, dan latar pembicaraannya.

Variasi atau ragam bahasa ini ada dua pandangan. Pertama, variasi atau ragam bahasa itu dilihat dari sebagai akibat adanya keragaman sosial penutur bahasa itu dan keragaman fungsi bahasa itu. Kedua, variasi atau ragam bahasa itu sudah ada untuk memenuhi fungsinya sebagai alat interaksi dalam kegiatan masyarakat yang beraneka ragam (Chaer dan Agustina, 2010:62). Tidak ada suatu bahasa di dunia ini yang tidak memiliki variasi. Variasi dapat berwujud perbedaan antara kelompok orang. Namun, variasi ini masih melingkupi pola atau dasar yang sama. Variasi ini antara lain disebabkan oleh pengaruh bahasa tetangga, seperti bentuk kosa kata, struktur, dan lafalnya (Keraf, 2008: 143).

Menurut Chaer dan Agustina (2010:62) variasi bahasa dibedakan berdasarkan penutur dan penggunaannya. Berdasarkan penutur, berarti 
siapa yang menggunakan bahasa itu, di mana tinggalnya, bagaimana kedudukan sosialnya di dalam masyarakat, apa jenis kelaminnya, dan kapan bahasa itu digunakan. Berdasarkan penggunaannya, berarti bahasa itu digunakan untuk apa, dalam bidang apa, apa jalur dan alatnya, dan bagaimana situasi keformalannya.

\section{METODE PENELITIAN}

Bentuk dan strategi penelitian ini terarah pada penelitian kualitatif yang bersifat deskriptif. Penelitian ini mengarah pada pendeskripsian secara rinci dan mendalam mengenai hal-hal yang ditemukan dalam sasaran penelitian. Jenis penelitiannya adalah penelitian dasar, yang bertujuan untuk memahami suatu masalah yang mengarah pada manfaat teoretik (Sutopo, 2009:136). Pemilihan jenis penelitian dasar disesuaikan dengan manfaat yang ingin dicapai pada penelitian ini yaitu diperolehnya pemahaman bagi pembaca atau masyarakat mengenai kebahasaan dalam film Toba Dreams.

Pada penelitian ini akan dikaji tentang penggunaan bahasa percakapan tokoh sebagai sarana komunikasi sosial, yang pelaksanaannya mengandalkan manusia (peneliti) sebagai instrumen pengumpul data. Peneliti mengumpulkan data yang berwujud wacana percakapan dalam film Toba Dreams yang mencakup kalimat, gugus kalimat, alinea, penggalan percakapan, dan percakapan utuh. Selanjutnya satuan lingual itu dideskripsikan sesuai dengan variasi bahasa yang terdapat di dalamnya. Metode ini dikenal sebagai metode deskriptif, yaitu metode dengan menggunakan teknik mencari data, mengumpulkan, menganalisis, dan mengelompokkannya berdasarkan fenomena-fenomena yang ada. Menurut Sumarsono (2007) metode deskriptif adalah pencarian fakta dengan interpretasi yang tepat.

Data yang digunakan dalam penelitian ini adalah dialog antar tokoh film Toba Dreams wacana yang disutradarai oleh Benny Setiawan. Penyediaan data dilakukan dengan metode simak, dengan menyimak dan memahami data-data kebahasaan yang berupa bahasa lisan dalam sumber data dialog antar tokoh. Teknik yang digunakan adalah teknik rekam dan catat. Teknik rekam digunakan oleh peneliti untuk merekam dialog film Toba Dreams. Teknik selanjutnya adalah teknik catat. Data yang telah diunduh ditulis agar dapat mempermudah analisis kebahasaan.

\section{HASIL DAN PEMBAHASAN}

Toba Dreams sebuah film yang menggambarkan sebuah perjuangan seorang ayah pensiunan TNI mendidik anaknya untuk ikut dengan jalan hidupnya. Hidup dengan uang pensiunan di tanah Leo Wira Hardiono, Variasi Bahasa .............. (1-13) 
Batak yang serba sederhana memaksa Ronggur anak pertama dari sersan TB memberontak karena menurutnya hidup di kampung danau Toba membuat Ronggur tidak berkembang. Akhirnya Ronggur lari ke Jakarta dan terjebak dalam lingkungan $b$ andar narkoba. Dalam dialog film Toba Dreams terdapat beberapa variasi bahasa karena latar belakang etnis tokoh yang berbeda.

Dalam film Toba Dreams ini, dapat dilihat adanya variasi bahasa dari para punutur yang berkaitan dengan dialek dan sosiolek para penutur.

\section{Dialek}

Pada dialog film Toba Dreams terdapat berbagai macam dialek yang digunakan oleh para penutur dalam keluarga sersan TB dan orang lain di sekitarnya untuk berkomunikasi, antara lain berbahasa Indonesia dialek Batak, dialek Medan, dialek Jakarta, dan dialek bahasa Jawa.

\subsection{Dialek Batak}

Variasi bahasa dalam latar belakang budaya Batak yang menyapa keluarga sersan $\mathrm{TB}$ saat tiba di kampung halaman orang tuanya terlihat dalam kutipan berikut.

\section{Dialog 1}

Warga : Bah.. Horas Pak TB. Na ro do ho Pak TB?
Pak TB : Bah.. Horas!

Dialog tersebut menggambarkan dialek Batak antara warga dengan Pak TB. Warga menanyakan kedatangan Pak TB dari Jakarta dengan Na ro do ho. Ucapan 'horas' merupakan salam dari orang Batak.

Dialek Batak juga terdapat pada kutipan dialog antartokoh di bawah ini.

$$
\begin{aligned}
& \text { Dialog } 2 \\
& \text { Ronggur : Dia pikir hidup dia } \\
& \text { lebih baik dari } \\
& \text { hidup gua. Ini } \\
& \text { Bapak saya Prajurit. } \\
& \text { Tentara. Tapi } \\
& \text { tentara yang } \\
& \text { kelaparan. } \\
& \text { Pak TB : Kurang ajar } \\
& \text { (memukul } \\
& \text { Ronggur) }
\end{aligned}
$$

Dalam dialog muncul dialek Batak ai ho doi Tigor oleh Mama Tigor yang memarahi Tigor karena mabuk-mabukan. Kalimat Dang hea diurupi on au mama dalam kalimat 
tersebut menjelaskan bahwa Tigor tidak pernah membantu ibunya bekerja.

Dialek Batak juga tergambar dari dialog antara pendeta yang memberkati pernikahan Ronggur dan Andini dalam gereja.

\section{Dialog 3 \\ Pendeta : Dipasu-pasu jala diramoti Tuhan \\ Debatama hamu. \\ Disondanghon \\ Tuhan Debatama \\ bohina tu hamu. Jala \\ asima rohana di \\ hamu. \\ Didompakhon \\ Tuhan Debatama \\ bohina tuhamu. Jala \\ dipasaorhon ma \\ damena tu \\ tondimuna be. \\ Amen.}

Ungkapan tersebut merupakan dialek Batak yang diungkapkan oleh tokoh pendeta dalam film Toba Dreams yang artinya pemberian berkat saat pemberkatan pernikahan di gereja. Semoga Tuhan memberkati pasangan suami istri, diberi kasih oleh Tuhan, dan diberi damai.

Variasi bahasa dialek Batak terdapat dalam kutipan ketika adek Ronggur membacakan kata perpisahan ketika ditempat pemakaman Ronggur.

\author{
Dialog 4 \\ Pendeta : Ale Ronggur \\ Maruhun. Sian tano \\ do parmulaan ni \\ dagingmu. Mulak \\ mai gabe tano. Ale \\ Tuhan Debata na \\ manompaho. Dohot \\ Tuhan Jesus Kristus \\ na manompaho sian \\ dosa dohot tondi \\ porbadia ma na \\ manjouhi ho tu \\ haangoluan naso \\ rasuda ima \\ mangaramoti orbuk \\ ni bakkem. Paima ro \\ ari parpudi.
}

Dialog tokoh pendeta di atas merupakan upacara saat penguburan kematian. Inti dari pernyataan tersebut adalah bahwa hidup adalah dari tanah dan kembali ke tanah. Tuhanlah yang menjaga dia dan memberkati orang yang telah meninggal, sampai pada pemanggilan di akhirat nanti.

\section{2 Dialek Jakarta}

Variasi bahasa Indonesia dialek Jakarta dapat dilihat dari dialog antara Ronggur, asisten bandar narkoba, dan bos bandar narkoba. Berikut tuturannya.

\section{Dialog 1}

Ronggur : bangsat, loe jebak gue? 


$\begin{array}{ll}\text { Asisten } & \text { : he.. jangan coba-coba. } \\ \text { Bos } & \text { : ingat cita-cita loe, jadi } \\ & \text { kaya raya. Kalau } \\ & \text { kamu jadi supir taksi } \\ & \text { sampai mati pun } \\ & \text { kamu nggak akan } \\ & \text { kaya. } \\ & \text { : dan loe juga harus } \\ \text { Asisten } & \text { inget, foto loe sudah } \\ & \text { ada pada kami. } \\ \text { Ronggur } & \text { loe gak bisa jebak gue, } \\ & \text { loe bangsat. } \\ \text { Bos } & \text { : he.. tunggu waktu tiga } \\ & \text { hari untuk jadi kaya } \\ & \text { atau menyesal? }\end{array}$

Dialog 2

Teman ronggur: loe masa urusan kayak gitu kagak ngerti sih dan begoknya loe mau disuruh-suruh sama orang yang baru loe kenal.

Ronggur : itulah gobloknya gue. Gue udah mikir sejauh itu tong.

Teman ronggur: ya wajarlah gak mikir sejauh ini yang ada di kepala loe kan Cuma duit. Dan gini aja deh malam ini loe lapor ke polisi jelasin ke semuanya terkait itu semua gimana prosesnya.

Ronggur : proses gimana maksud loe. Loe mau semua mati?
Adanya bahasa Indonesia dialek Jakarta yang diujarkan oleh tokoh Ronggur tersebut meliputi kata loe 'kamu' sapaan untuk kata ganti orang kedua tunggal kata gue 'saya' merupakan sapaan untuk menyebutkan kata ganti orang pertama tunggal.

\subsection{Dialek Medan}

Terdapat dialek Medan dalam percapakan Togar (teman Ronggur) ketika menjelaskan budaya orang medan kususnya Batak terkait kuburan rumah huni terakhir manusia ketika mati.

$\begin{array}{cl}\text { Togar } \quad & \text { John, kau tengok } \\ & \text { bangunan-banguan } \\ & \text { besar itu. Itu bukan } \\ & \text { rumah. Itu kuburan } \\ & \text { sama kayak di sini. } \\ & \text { Nah tengok ini } \\ & \text { kuburan itulah orang } \\ & \text { Batak ini datang } \\ & \text { merantau bukan bawa } \\ & \text { uang bawa mayat. } \\ & \text { Biar kau tau, bikin } \\ & \text { kuburan besar-besar } \\ & \text { kali biar terpandang } \\ \text { pada saat matinya. } & \text { Kita juga yang tak } \\ \text { mampu berlomba- } & \text { lomba sampek utang } \\ \text { padahal rumah } \\ \text { mereka beh kesrebet } \\ \text { angin kentut juga } \\ \text { udah roboh rumah }\end{array}$


mereka. Miris kan John.

Dialog tokoh Togar tersebut menggambarkan dialek Medan seperti 'Kau Tengok' yang artinya dalam bahasa Indonesia 'kamu lihat'.

\subsection{Dialek Jawa}

Variasi bahasa dialek Jawa yang digunakan ibu Ronggur kepada Andini yang menawarkan ibadah sholat, berikut kutipan dilalognya.

Ibu Ronggur : kamu sudah sholat? Andini : Belum bu...

Ibu Ronggur : Nek koe arep sholat, Ibu ndak masalah. Opung wes ngejenke. Tapi koe takon sek karo bapak yoh... seng due omah.

Berdasarkan dialog tokoh tersebut bisa dilihat terdapat dialek Jawa. Kata nek yang artinya 'kalau' . Terdapat juga kata ndak memiliki arti dalam bahasa Indonesia 'tidak'. Kata wes yang berarti 'sudah' terdapat juga kata dialek Jawa ngejenke yang artinya dalam bahasa Indonesia 'mengijinkan'. Kata takon dalam bahasa Indonesia yang memunyai arti 'tanya' atau menanyakan kepada seseorang. Kata karo yang memunyai arti 'dengan' dalam bahasa Indonesia merupakan kata hubung.
Kata yoh yang memiliki arti 'ya'. Kalimat terakhir seng due omah dalam bahasa Indonesia memiliki arti 'yang punya rumah.

Dalam dialog antartokoh film Toba Dreams tersebut mengambarkan pemakaian dialek Jawa dilakukan Ibu Ronggur asli keturunan Jawa.

\section{Sosiolek}

Pada film Toba Dreams variasi sosioleknya meliputi pendidikan dan pekerjaan. Di bawah ini disajikan data yang mengandung sosilek.

\subsection{Pendidikan}

Ketika adik Ronggur yang sudah mengenyam pendidikan sekolah pendeta komunikasi yang dilakukan telah berbeda pada saat ia masih sekolah SMA. Pelafalan yang semakin baik dan makna kata yang dilafalkan juga mengandung arti religius sama dengan statusnya sebagai pendeta. Seperti kutipan dialog berikut.

Ronggur : : Makasih dek..

Adik Ronggur : sama-sama bang..

Ronggur : bersyukur pada Tuhan..

Adek Ronggur : Abang sudah kembali ke rumah. Ada apa bang? Abang belum bisa bawa istri dan anak abang ke sini (gereja). Jangan salahkan mereka 


\author{
bang, abang sudah \\ bukakan pintu \\ untuknya tapi \\ abang tidak \\ embawa mereka \\ masuk. Bang mulai \\ sekarang \\ bukakanlah hati \\ abang mulai \\ dengan cinta kasih. \\ Tuhan pasti \\ menyayangi abang \\ dan keluarga \\ abang.
}

Dialog tersebut menggambarkan bahwa adik Ronggur telah memiliki status pendidikan tinggi menjadi seorang pendeta dan memberikan masukan kepada abangnya (Ronggur) yang status pendidikannya dibawah adiknya menjadi pengedar narkoba kelas kakap.

\subsection{Pekerjaan}

Berdasarkan pekerjaan dapat dilihat pada perbedaan bahasa yang digunakan, hal tersebut terjadi karena lingkungan pekerjaan dan apa yang mereka kerjakan berbeda sehingga terdapat variasi bahasa terutama akan tampak pada bidang kata yang digunakan. Seperti contoh tuturan berikut.

$$
\begin{gathered}
\text { Sersan TB : Rekan-rekan prajurit } \\
\text { yang saya cintai dan } \\
\text { saya banggakan, }
\end{gathered}
$$

meskipun saya sudah tidak ada lagi di sini, tapi hati saya, jiwa saya, saya tinggalkan di sini. Saya berharap semoga rekan-rekan prajurit membanggakan nusa dan bangsa. Selamat bertugas!

Tuturan Sersan TB yang menunjukkan kata 'prajurit' tersebut lekat dengan pekerjaan menjadi anggota berpangkat lebih rendah. Ketika itu ia memberikan sambutan terakhir kepada semua anggota TNI dan pimpinan TNI bahwa meskipun sersan TB sudah pensiun dari prajurit aktif ia tetap memberikan jiwa raganya untuk mengabdi pada negara.

Selain itu dialog antara Ronggur beserta asisten mafia narkoba menunjukkan ketika keberangkatan dari Pulau Toba ke Jakarta dan menjalani pekerjaan supir taksi dan pekerjaan penum-pang taksinya sebagai pentolan gembong narkoba terdapat dalam dialog berikut.

Ronggur : maaf-maaf bos, dalam taksi tidak boleh merokok.

$\begin{array}{ll}\text { Asisten } & \text { : asal kita } \\ & \text { pengecualianlah, } \\ & \text { nanti kita tambah } \\ & \text { kok. } \\ \text { Ronggur } & \text { : tidak bisa bos, udah } \\ & \text { peraturannya begitu }\end{array}$




\begin{tabular}{|c|c|}
\hline & $\begin{array}{l}\text { soalnya, maaf- } \\
\text { maaf... }\end{array}$ \\
\hline Asisten & $\begin{array}{l}\text { : kalo gue merokok } \\
\text { loe mau apa, hah? }\end{array}$ \\
\hline Ronggur & $\begin{array}{l}\text { silakan cari taksi lain } \\
\text { dan maaf-maaf... }\end{array}$ \\
\hline Asisten & $\begin{array}{l}\text { : he.. bangsat gak usah } \\
\text { larang-larang gua } \\
\text { ngerokok kalau loe } \\
\text { gak mau nyesel! }\end{array}$ \\
\hline Ronggur & $\begin{array}{l}\text { : kalau loe pada mau } \\
\text { merokok keluar. } \\
\text { Saya tunggu! }\end{array}$ \\
\hline Asisten & $\begin{array}{l}\text { gimana kalau kepala } \\
\text { loe gua pecahkan. } \\
\text { Loe lalu gua seret } \\
\text { mayat loe keluar? }\end{array}$ \\
\hline Ronggur & $\begin{array}{l}\text { : Rokok memang bisa } \\
\text { ngebunuh tapi kalau } \\
\text { ada orang ngebunuh } \\
\text { gua gara-gara } \\
\text { ngerokok, bunuh tuh } \\
\text { orang, keluar loe } \\
\text { semua keluar! }\end{array}$ \\
\hline Asisten & : monyet loe! \\
\hline
\end{tabular}

Tuturan Ronggur ketika bekerja menjadi supir taksi dengan gerombolan mafia narkoba sangatlah berbeda. Ketika gaya komunikasi Ronggur yang ramah memberikan himbuan bahwa dalam taksi dilarang merokok dan dibalas oleh bos pengedar narkoba beserta asistennya dengan kata bangsat dan monyet menggambarkan pekerjaanya sebagai pengedar narkoba (penjahat). Kalimat yang menggambarkan bahwa mafia narkoba sangat nekat ter- kait dengan perkataan yang menggertak Ronggur. Kalimat gertakan tersebut Loe lalu gua seret mayat loe keluar? bahwa dalam situasi tersebut Ronggur di todong pistol lalu menembakkan pistolnya dan menyeret mayat Ronggur keluar dari mobil.

\section{SIMPULAN}

Ragam bahasa merupakan varian dari sebuah bahasa menurut pemakaian. Terdapat wujud variasi dialek dalam film Toba Dreams antara lain dialek Batak, dialek Jakarta, dialek Medan, dan dialek Jawa. Variasi sosiolek dalam dialog antartokoh film Toba Dreams meliputi pendidikan dan pekerjaan. Dalam hal pendidikan ditunjukkan oleh adik Ronggur yang menjadi seorang pendeta lewat sekolah pendeta yang menjadi pilihannya. Semua dapat diketahui lewat bahasa komunikasi yang condong religius. Dalam hal pekerjaan ditunjukkan sersan TB yang memberikan sambutan ketika akan pensiun. Serta Ronggur yang bekerja menjadi supir taksi berdialog dengan gerombolan mafia narkoba. Semua terlihat ketika gerombolan mafia narkota tersebut berkata yang mengandung unsur negatif seperti bangsat, bajingan, dan kalimat Loe lalu gua seret mayat loe keluar. 


\section{DAFTAR PUSTAKA}

Alwasilah, A. Chaedar. (2012). Pengantar Sosiologi Bahasa. Bandung: Penerbit Angkasa.

Chaer, Abdul dan Leonie Agustina. (2010). Sosiolinguistik: Perkenalan Awal. Jakarta: Rineka Cipta.

Effendy, Onong Uchjana. (2007). Ilmu Komunikasi. Bandung: Remaja Rosdakarya.

Keraf, Gorys. (2008). Diksi dan Gaya Bahasa. Jakarta: PT. Gramedia Pustaka Utama.

Kridalaksana, Harimurti. (2008). Kamus Linguistik. Jakarta : Gramedia Pustaka Utama.
Ohoiwutun, Paul. (2007). Sosiolinguistik: Memahami Bahasa dalam Konteks Masyarakat dan Kebudayaan. Jakarta: Visipro.

Rahadi, Kunjana. (2010). Kajian Sosiolinguistik. Yogyakarta : Ghalia Indonesia.

Sumarsono dan Paina Partana. (2007). Sosiolinguistik. Yogyakarta: Pustaka Pelajar.

Sutopo. (2009). Metodologi Penelitian Kualitatif. Surakarta: UNS

"Toba Dreams" dalam https://www. youtube.com/watch?v=Ik6ahVpx 0-s, diakses 10 Maret 2018.

Wijana, I Dewa Putu. (2010). Sosiolinguistik Kajian Teori dan Analisis. Yogyakarta: Pustaka Pelajar. 